DOI : 10.24260/khatulistiwa.v9i1.1308

\title{
REPRESENTATION OF SAPARDI DJOKO DAMONO'S POETRY IN ISLAMIC EDUCATION: A SEMIOTIC STUDY
}

\author{
Heny Anggreini \\ Gadjah Mada University \\ Email: anggreiniheny@yahoo.com
}

\section{HIGHLIGH}

- Sapardi Djoko Damono's poetry of Hatiku Selembar Daun, Yang Fana Adalah Waktu, and Akulah Si Telaga, provide Islamic education teaching for the society as the readers

ARTICLE HISTORY

$\begin{array}{lll}\text { Submitt } & : & 05 \text { Mar } 2019 \\ \text { Revision } & : & 24 \text { Feb } 2019 \\ \text { Revision } & : & 2 \text { Mar } 2019 \\ \text { Minor } & & \end{array}$

Accepted : 5 Mar 2019

Published : 30 Mar 2019

\section{Keyword : $\quad$ Islamic education, myth, poetry}

The poetry analyzed are "Hatiku Selembar Daun", "Yang Fana Adalah Waktu", and "Akulah Si Telaga". The poetry are analyzed using qualitative research methods, which are analyzed descriptively through words, lines, and verses, using Roland Barthes's semiotic theory. The results of this study explain that the myth that Barthes interpreted as an ideology delivered by poets in his poetry to instill the view of Islam in living life because of moral degeneration that occurs in humans today. Through the poetry, the poet contests his ideology about attitudes and traits that must be possessed by humans based on the teachings of Islam, that: First, humans are very fragile creatures. Second, there is no eternity on this earth. Third, sacrifices that do not ask for rewards or profit.

(C2019 Khatulistiwa All Rights Reserved

DOI: $10.24260 /$ khatulistiwa.v9i1.1308

Representation of Sapardi Djoko Damono's Poetry in Islamic Education; A Semiotic Study
KHATULISTIWA: Journal of Islamic Studies Vol. 9, No. 1. March 2019 


\section{A. INTRODUCTION}

Culture is a meaning system used for marking process (Budiman, 2004: 105). Culture is patterns of meaning which contain ideas, thoughts, and actions that have pattern and meaning. Thus, literature is a part of culture. It is explained by literature which plays a role as a manifestation of human life which contains cultural phenomena. Sapardi Djoko Damono's poetry such as Hatiku Selembar Daun, Yang Fana Adalah Waktu, and Akulah Si Telaga are the practices of meaning which exist in life that help in shaping the culture. As the practices of meaning that shape the culture, Sapardi's poetry describe the nature and soul of human, as a weak creature, which is unable to control the will (desires), has unstable belief, and never escape from mistakes. All of them are reproduced in the social order. Therefore, poetry is a place to express and reproduce social order.

Poetry is considered to have aesthetic value. Moreover, poetry also has a broad and growing meaning which is called connotation, which in turn becomes a myth (it can be called ideological operation by Barthes) because it is represented continuously. Poets create poetry for political purposes and spreading religion. In poetry, poets convey a bunch of life fluctuations such as: social, cultural, educational, political, religious, environmental, and other problems. However, the main purpose of creating a work is to spread the myth to the reader. The readers are presented with various ideologies.

Sapardi Djoko Damono poured all his anxieties into poetry, both the anxiety about himself and other humans or the social environment. The poetry he created have a myriad of meanings because the meanings are constructed and produced. Because meaning is constructed and produced, it is very important to connect poetry with the accompanying culture. The poetry which are conveyed by Sapardi have

KHATULISTIWA: Journal of Islamic Studies Vol. 9, No. 1. March 2019
DOI: 10.24260/khatulistiwa.v9i1.1308

Representation of Sapardi Djoko Damono's Poetry in Islamic Education; A Semiotic Study 
ideologies that are deliberately or unintentionally contested and negotiated to improve or destroy the power of other views (ideologies).

The poetry of Hatiku Selembar Daun, Yang Fana Adalah Waktu, and Akulah Si Telaga, negotiate religious ideology. The ideology is contested because Indonesian people need to be instilled with religious views because there are at least "humanist" people. Seeing the chaotic life in Indonesia, Sapardi poured out his anxiety in the form of poetry that provide Islamic education. Here, poetry has important roles for the society. It opens the mindset of society - forming and maintaining the character. This time, it is important to islamize Muslims because of the many crimes, duping characters, and liberal thoughts that enter and are accepted by the society.

This research discusses three poetry from Sapardi Djoko Damono which have religious theme. The religious theme in a poetry will provide Islamic education which give positive impacts to the soul and emotions that humans have. It is because basically, poetry is language and meaning that are interconnected with culture. This culture will be an ideology - a view which is constantly being negotiated. Hence, it is very important to include ideologies that originate from Islamic education to the society before being preceded by Western culture. Based on these problems, the problem discussed is how is the representation of Sapardi Djoko Damono's poems for Islamic education? Thus, it will achieve the objectives of this research, namely by knowing the representation of Sapardi Djoko Damono's poetry, it will explain the role of poetry in human life in forming the characters which contain Islamic education.

There are previous studies which have a relevance in terms of the concepts used, namely the research that was conducted by R.A Granita Dwisthi Ismujihastuti and Adi Bayu Mahadian (2015), which discusses women in the album cover of Raisa. Women are represented in the cultural construction of the society as creatures that have long, unraveled hair, use dresses, accessories, and natural make-up. The

KHATULISTIWA: Journal of Islamic Studies Vol. 9, No. 1. March 2019
DOI: 10.24260/khatulistiwa.v9i1.1308

Representation of Sapardi Djoko Damono's Poetry in Islamic Education; A Semiotic Study 
construction is produced continuously by women as a culture that has lived in the society, so that it becomes a myth for every woman.

Barthes said that human life has been dominated by connotations. The connotation moves in life based on the sign users with their perspective. If connotation has mastered the life, it will become a myth (Hoed, 2007: 4). Talking about representation, definitely, it relates between meaning and language with culture (Hall, 1997: 15). It means that language as a sign has meaning, which is related to the culture of the society or region. That is because everything in this world is a symbol. The symbols have meaning. To simply put, representation is the production of meaning through language. Therefore, language is the second representation system which is involved in the whole process of meaning building (Hall, 1997: 1617). The relationship between 'things', concepts, and signs lies at the heart of the production of meaning in language. The process that links these three elements together is what we call 'representation' (Hall, 1997: 19). It can be concluded that meaning is not attached or attached to these objects as 'fitted' (read: fixed, so it cannot be changed), but the meaning is constructed and produced. It is the result of a practice that signifies - a practice that produces meaning, so that everything has meaning (Hall, 1997: 24).

Semiotics is defined as study of signs in community life, while culture constitutes the system of meaning. Through this system, social structure is communicated, produced, experienced, and explored (Budiman, 2004: 105 in Barnard, 1996). By limiting culture only as system of meaning and sign, central concept of every semiotic can be attained: concept of sign. Talking about sing means talking about 'signifier' or 'significant' and 'signified' or 'signify'. 'Signifier' is a sign element that is reality, physique, and material, while 'signified' is a mental concept or meaning referred by 'signifier'.

KHATULISTIWA: Journal of Islamic Studies Vol. 9, No. 1. March 2019
DOI: 10.24260/khatulistiwa.v9i1.1308

Representation of Sapardi Djoko Damono's Poetry in Islamic Education; A Semiotic Study 
The theory used in this analysis is Roland Barthes's approach. Barthes divided the process of meaning in two stages, namely denotation and connotation. The process of meaning at the first level is denotation, namely the literal meaning of an object or image: what is depicted in the object or image. While the meaning system at the second level is connotation. Connotation is a deep digging of meaning - the development of a sign by a sign user according to the point of view. Or it can be said that connotation is a concept, thought, or certain cultural theme (Budiman, 2004: 107). The concept, mind, and cultural theme developed among language users based on their perspectives, and the situation continues and dominates the society, so it will become a myth. Hence, the meaning of the second level (connotation) is myth, namely the ideological process of speech, which presents ideological fragments. In other words, the meaning of the second level (connotation) is ideological meaning which is produced.

Various ideologies are produced in human life, one of them is the ideology of Islamic education which really needs to be understood because it will shape the character of the nation. Education is an effort to internalize values in leaning process in order to achieve certain purpose (Kurniawan, 2008: 23). Then, according to alGhazali, the purpose of education is to enable human to have knowledge which is applied in his life for the sake of ridhallah. al-Ghazali also mentions that all people will lose out except those who have knowledge; those who have knowledge will lose out except which implement their knowledge; and people who implement their knowledge will lose out except those who are genuine (Hasan in Kurniawan, 2008: 25).

The values based on Islamic teaching and according to al-Qur'an and Hadith are internalized through Islamic education (Kurniawan, 2008: 23). And the purpose of Islamic Education is not only to create smart and intellectual people but also create people who have good akhlaq and character (Hasan in Kurniawan, 2008: 25). If

KHATULISTIWA: Journal of Islamic Studies Vol. 9, No. 1. March 2019
DOI: 10.24260/khatulistiwa.v9i1.1308

Representation of Sapardi Djoko Damono's Poetry in Islamic Education; A Semiotic Study 
intellectual people are not religious they will only be harmful and greedy like a proverb: human without knowledge will be blind and human without religion will be paralyzed. Thus, having both knowledge and religion will make the world so peaceful.

Teaching Islamic knowledge to young generation will give positive effect for a nation, and without akhlaq, human will only be greedy and never be thankful to rahmat granted by Allah. Such kind of person will only be harmful for he has been already out of right track shown by al-Qur'an and Hadith.

Education should be based on Islamic teaching in order that children will have good character, soul, body, free will, and mind (Langgulung in Suradi, 2018: 10). The free will mentioned here is not a freedom without any control. It is free thought or viewpoint to express or criticize a problem. In other words, it is free to do something according to one's way of thinking to know the truth without breaking the rule.

There are well known terms related to $a d a b$ in Islamic teaching: adab addunya and adab addin. Adab addunya means that education aims to create tashkir (technology) in order to live comfortably in dunya, while the latter intends to create tazkiyah (soul purity) and ma'rifah which leads to ukhrawi happiness (Suradi, 2018: 13).

\section{B. RESEARCH METHOD}

The method used in this research is qualitative research method which leads to the content analysis (Udasmoro, 2012: 36). The data source in this research is Sapardi Djoko Damono's poetry of Hatiku Selembar Daun, Yang Fana Adalah Waktu, and Akulah Si Telaga. The data in this research are in the form of words, lines, and verses in those three poetry. The researcher acts as an instrument that selects the data and focuses on the data needed (Siswantoro, 2010). The data collection was carried out through these following steps: 1) reading data repeatedly, 2) classifying data, 3) selecting data that are considered relevant to the problem, question, or purpose of the

KHATULISTIWA: Journal of Islamic Studies Vol. 9, No. 1. March 2019
DOI: 10.24260/khatulistiwa.v9i1.1308

Representation of Sapardi Djoko Damono's Poetry in Islamic Education; A Semiotic Study 
research, 4) conducting data analysis, 5) making research reports. The data collected will be analyzed using Roland Barthes's semiotic theory which assumes that the meaning or content of a sign will become a myth if it has mastered the society (Hoed, 2007: 4).

\section{RESULT AND DISCUSSION}

\section{Representation of Sapardi Djoko Damono's Poetry}

Representation is connected to meaning, language, and culture. Studyingrevealing Sapardi's poetry aims to share myth or ideology postulated by the poet. The poetry constitutes meaningful language produced and constructed by culture in order to result mythology as the poetry of 'Hatiku Selembar Daun':

Hatiku selembar daun melayang jatuh di rumput// nanti dulu, biarkan aku sejenak// terbaring di sini// ada yang masih ingin kupandang// yang selama ini senantiasa luput// Sesaat adalah abadi sebelum kausapu// tamanmu setiap pagi//

Analysis: 'Hatiku' 'selembar' 'daun' 'melayang' 'jatuh' di 'rumput', according to Barthes, this is categorized as second phase (connotation): fragility. Then: nanti dulu, biarkan aku 'sejenak'// 'terbaring' di sini// ada yang masih ingin 'kupandang'// yang selama ini senantiasa 'luput', has connotation meaning that regret. It shows that human character tends to be lost whereas, even in difficult situation, his heart should remain istiqamah.

Last: 'Sesaat adalah 'abadi' sebelum 'kausapu'// 'tamanmu' setiap 'pagi' has connotation meaning that he feels never ending guilty; feels that life is eternalforgets that human is only slave of Almighty Allah, and He has power to vanish — send disaster to everyone He determines to have it.

Holistically, the poetry of 'Hatiku Selembar Daun' connotatively means that humancharacter is as fragile as leaf and is easy to be flown by wind. Sapardi explains

KHATULISTIWA: Journal of Islamic Studies Vol. 9, No. 1. March 2019
DOI: 10.24260/khatulistiwa.v9i1.1308

Representation of Sapardi Djoko Damono's Poetry in Islamic Education; A Semiotic Study 
instability or human character following those who give pleasure, satisfaction, and enjoyment. Human often forgets his duties in the world especially when he lives in comfortable and cozy place. Human is easy to be agitated particularly when he feel happy and enjoyable. Thus, without test or ordeal he will be careless, arrogant, and irresponsive. He thinks that he is immortal and forgets the present of Allah who can easily take away anything He wants.

Myth (mythology) in the poetry of "Hatiku Selembar Daun" is generated because humans have fragile hearts, so people often make mistakes or forgetfulness when they enjoy the test of sadness and happiness. Human cannot escape from making mistakes, then a way to return to the right and good path is provided, namely hijrah and repenting. Hijrah is conducting an action for goodness and turning into a better person. While, when humans commit an error — sinning, then the only way to return to the right path is only by repenting. Fragility which is owned by every human being requires humans to be strong and patient in facing each test and keep being consistent in carrying out Allah's commands and prohibitions. It is the representation of human nature in worshiping the God, and there will be ups and downs.

The Poetry of 'Yang Fana Adalah Waktu':

Yang fana adalah waktu. Kita abadi:// memungut detik demi detik, merangkainya seperti bunga// sampai pada suatu hari// kita lupa untuk apa.// "Tapi, yang fana adalah waktu, bukan?"// tanyamu.// Kita abadi.

Analysis: Yang 'fana' adalah 'waktu'. 'Kita' 'abadi':// 'memungut' 'detik demi detik', 'merangkainya' seperti 'bunga'// sampai pada 'suatu hari'// kita 'lupa' 'untuk apa', connotatively means impermanence and greed, while human is playing gamedreaming to have everything he wants in the world. Human never be thankfulalways feels inadequate. When he is aware-Allah shows him to the way to get backhe questions himself. “Tapi, yang 'fana' adalah 'waktu', 'bukan?'”// tanyamu.// 'Kita' 'abadi'. This statement shows that human character is stubborn, forgettable, and careless-irresponsive, making him arrogant. There is no immortality in this world,

KHATULISTIWA: Journal of Islamic Studies Vol. 9, No. 1. March 2019
DOI: 10.24260/khatulistiwa.v9i1.1308

Representation of Sapardi Djoko Damono's Poetry in Islamic Education; A Semiotic Study 
but human refuses his pure heart-mind because of his arrogance is deep inside his heart.

Completely, the poetry of 'Yang Fana Adalah Waktu' denotatively means that there is no immortality in the word, but Sapardi makes a contradiction by contrasting human with immortality, whereas human is not eternal and the immortal place is only akhirah. Human is greedy and does anything to get what he wants-his desire must be fulfilled without realizing that all he wants is not what he needs - doing everything only to indulge his lust. In the last line: Tapi, yang fana adalah waktu, bukan?"// tanyamu.// Kita abadi// means that human is greedy even he knows that what he does is vain, and will never run after the time-human is always left behind and rushed but his lust makes him forget that he is not immortal.

Myth (mythology) in the poetry of "Yang Fana Adalah Waktu" is that time is like a spinning wheel which cannot return. Life runs because of time. The poetry explains human immaturity, human greed, and arrogance. Humans are negligent creatures. However, the human nature which is hard influence them to close their eyes and heart. Even though humans know that nothing is eternal, humans still do it. It means that they try to cover up the truth to fulfill their desire which is temporary pleasure. If humans do not use their time properly (negligently), they will be left behind in the cycle of life. The time passed without doing something positive is a futile act. Humans will only experience regret in their lives.

Poetry of 'Akulah Si Telaga':

akulah si telaga: berlayarlah di atasnya// berlayarlah menyibakkan riakriak kecilyang menggerakkan// bunga-bunga padma// berlayarlah sambil memandang harumnya cahaya// sesampai di seberang sana, tinggalkan begitu saja//_ perahumu biar aku yang menjaganya//

analysis: 'akulah' si 'telaga': 'berlayarlah' di 'atasnya'// 'berlayarlah' 'menyibakkan' 'riak-riak kecil' yang 'menggerakkan'// 'bunga-bunga padma'// 'berlayarlah' sambil 'memandang' 'harumnya' 'cahaya', connotatively means that a mother will sacrifice

KHATULISTIWA: Journal of Islamic Studies Vol. 9, No. 1. March 2019
DOI: 10.24260/khatulistiwa.v9i1.1308

Representation of Sapardi Djoko Damono's Poetry in Islamic Education; A Semiotic Study 
for her children and even tells-permits them to hurt her-takes away everything impedes them to reach their dream (for example is lotus). Mother lets her children enjoy their life. 'Sesampai di 'seberang' sana, 'tinggalkan' begitu saja//—-perahumu' biar 'aku' yang 'menjaganya', connotatively means that mother's sacrifice is so big; she lets her children go to reach their dream-leave their house. She lets herself have difficulty but she does not want to see her children suffer and have trouble.

Comprehensively, the poetry of 'Akulah Si Telaga' explains that 'telaga' is an ecosystem like a mother who sacrifices for her children life and happiness; she is always ready to let them go, taking care of her homeland, while her children leave her-go away to reach their dream or even worse become lawlessness. A boat can be considered as a burden, but it can also be a tool for her children to achieve their purpose. The role of mother is very crucial, she is ready to be abandoned-she is willing to be alone for her children's success.

The myth (Mythology) of the poetry of 'Akulah Si Telaga' is about a mother who never be happy when knowing that her children suffer or in trouble. She never leaves her children, and keeps supporting them in order to be successful. Becoming a mother means readiness to sacrifice herself for the sake of her children's happiness.

\section{Islamic Education in Sapardi Djoko Damono's Poetry}

Through his poetry 'Hatiku Selembar Daun, Yang Fana Adalah Waktu', and 'Akulah Si Telaga', Sapardi presents religious ideologies for the reason of Islamic education since religious teaching especially akhlaq is very important for youngsters moreover the technology and globalization do not only bring positive effect but negative effect as well. Islamic education can balance between akhlaq and intellectuality for human life. If imbalance immerges, it will become disaster for world-national generation. Surah Al-Mujadalah, verse 11:

KHATULISTIWA: Journal of Islamic Studies Vol. 9, No. 1. March 2019
DOI: 10.24260/khatulistiwa.v9i1.1308

Representation of Sapardi Djoko Damono's Poetry in Islamic Education; A Semiotic Study 


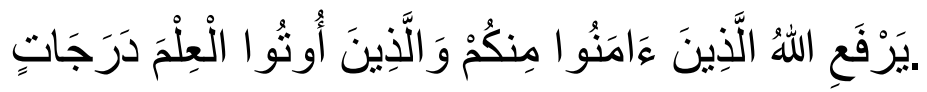

"Allah will raise those who have believed among you and those who were given knowledge, by degree".

It is obvious that life must be balanced: being knowledgeable without understanding religion will be harmful and being religious but fool will be in poverty. Islamic education is very essential since many people have bad akhlaq; they think too much about dunia-collect materials as many as possible, ignore their poor Muslim brothers, and do not feel guilty when taking property that does not belong to them. Human become greedy like animal: hurt each other, and are in dispute to get what they desire. The three poetry of Sapardi Djoko Damono can be used for Islamic education, that:

\section{Hatiku Selembar Daun (Self Fragility)}

This poetry tells that human heart is easily changed by Allah so that humans should be patient and perform prayer when their faith is tested; lesson of istiqamah through maintenance of goodness and truth. They should be strong-resilient because Allah tests His slave in order to raise his degree. Yet, he is often impatientangry with the test and unhappy when Allah loves him through the test. Such human characters should be fixed through Islamic education.

\section{Yang Fana Adalah Waktu (No Immortality)}

This poetry explains that there is nothing immortal but people often forget and do not care-keep pursuing happiness which is actually misery. They forget and are irresponsive when they are happy and secured. This poetry shows that human lives in artificiality - he hasto wake up from his dream - should not be in hurry and greedy which can make him forget the existence of Allah, the Creator-who manages human

KHATULISTIWA: Journal of Islamic Studies Vol. 9, No. 1. March 2019
DOI: 10.24260/khatulistiwa.v9i1.1308

Representation of Sapardi Djoko Damono's Poetry in Islamic Education; A Semiotic Study 
life. He needs exposing to Islamic education in order not to be arrogant and careless with the presence of the Creator.

\section{Akulah Si Telaga (Genuine Sacrifice)}

This poetry tells that mother's love is unlimited, and her sacrifice is genuine. She even sacrifices her happiness for her children's pleasure. She never asks for but she always gives, and never feels upset even being hurt. She drops her tears and always forgives her children. Islam tells Muslims to always love and obey their mother, never hurt her feeling.

\section{CONCLUSION}

The conclusions of this research are that Sapardi Djoko Damono's poetry of Hatiku Selembar Daun, Yang Fana Adalah Waktu, and Akulah Si Telaga, provide Islamic education teaching for the society as the readers. In those three poetry, Sapardi offered an ideology which is originated from the development of a meaning in society and continued to be produced by the society so that it becomes culture. First, humans are very fragile creatures. Second, there is no eternity on this earth. Third, sacrifices that do not ask for rewards or profit. Those three poetry teach Islamic education for the society. By understanding it as a view in life, life in this world will prosper. Instilling Islamic views in the poetry will certainly provide positive impacts to the character of the nation. Those three poetry teach Islamic values based on the Quran and Hadith. Islamic education is indispensable because it will generate young people who have moral character. Life will be safe and peaceful when all people know the importance of Islamic education which is applied.

KHATULISTIWA: Journal of Islamic Studies Vol. 9, No. 1. March 2019
DOI: 10.24260/khatulistiwa.v9i1.1308

Representation of Sapardi Djoko Damono's Poetry in Islamic Education; A Semiotic Study 


\section{BIBLIOGRAPHY}

Budiman, Kris. 2004. Jejaring Tanda-tanda; Strukturalisme dan Semiotik dalam Kritik Kebudayaan. Magelang: IndonesiaTera

Fauzi, Amin. 2017. Integrasi dan Islamisasi Ilmu dalam Perspektif Pendidikan Islam. Jurnal Pendidikan Islam, Vol 8 No. 1 (1-18)

Hall, Stuart. 1997. Representation: Cultural Rapresentations ang Signifying Practice. Sage Publictions: London

Hoed, Benny H. 2007. Semiotik dan Dinamika Sosial Budaya. Depok. Fakultas Ilmu Pengetahuan Budaya (FIB) UI

Ismujihastuti, Granita Dwisthi dan Adi Bayu Mahadian, 2015. Representasi Wanita dalam Sampul Album Raisa (Analisis Semiotik Roland Barthes terhadap Sampul Album Raisa Andriana "Raisa" dan "Heart to Heart"). e-Proceeding of Management: Vol 2 No. 1 (994-1007)

Kurniawan, Syamsul. 2008. Pendidikan Menurut Al-Ghazali. Jurnal At-Turats, Vol 3 No. 1 (23-29)

Siswantoro. 2010. Metode Penelitian Sastra: Analisis Struktur Puisi. Yogyakarta: Pustaka Pelajar

Suradi, A. 2018. Konsepsi Pendidikan Islam dalam Meningkatkan Kualitas Sumber Daya Manusia. Jurnal Pendidikan Islam, Vol 9, No.1 (1-18)

Internet:

Cahaya, Destiara. 2014. Kumpulan Puisi Sapardi Djoko Damono (internet). (diunduh 28 September 2018). Tersedia pada: http://was-was.com/2014/01/kumpulanpuisi- sapardi-djoko-damono.html

KHATULISTIWA: Journal of Islamic Studies Vol. 9, No. 1. March 2019
DOI: 10.24260/khatulistiwa.v9i1.1308

Representation of Sapardi Djoko Damono's Poetry in Islamic Education; A Semiotic Study 